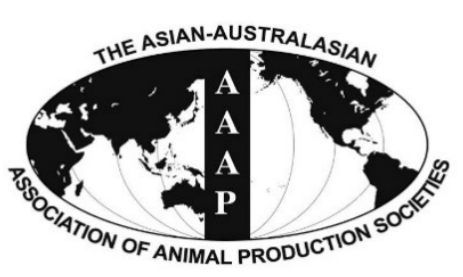

Open Access

Asian Australas. J. Anim. Sci.

Vol. 29, No. 8 : 1075-1082 August 2016

http://dx.doi.org/10.5713/ajas.16.0118

www.ajas.info

pISSN 1011-2367 elSSN 1976-5517

\title{
Stress, Nutrition, and Intestinal Immune Responses in Pigs - A Review
}

\author{
In Kyu Lee ${ }^{1}$, Yoon Chul Kye ${ }^{1}$, Girak Kim ${ }^{1}$, Han Wool Kim ${ }^{1}$, Min Jeong Gu, \\ Johnny Umboh ${ }^{2}$, Kartini Maaruf ${ }^{2}$, Sung Woo Kim ${ }^{3, *}$, and Cheol-Heui Yun ${ }^{1,4,5, *}$ \\ ${ }^{1}$ Department of Agricultural Biotechnology and Research Institute of Agriculture and Life Sciences, \\ Seoul National University, Seoul 08826, Korea
}

\begin{abstract}
Modern livestock production became highly intensive and large scaled to increase production efficiency. This production environment could add stressors affecting the health and growth of animals. Major stressors can include environment (air quality and temperature), nutrition, and infection. These stressors can reduce growth performance and alter immune systems at systemic and local levels including the gastrointestinal tract. Heat stress increases the permeability, oxidative stress, and inflammatory responses in the gut. Nutritional stress from fasting, antinutritional compounds, and toxins induces the leakage and destruction of the tight junction proteins in the gut. Fasting is shown to suppress pro-inflammatory cytokines, whereas deoxynivalenol increases the recruitment of intestinal pro-inflammatory cytokines and the level of lymphocytes in the gut. Pathogenic and viral infections such as Enterotoxigenic $E$. coli (ETEC) and porcine epidemic diarrhea virus can lead to loosening the intestinal epithelial barrier. On the other hand, supplementation of Lactobacillus or Saccharaomyces reduced infectious stress by ETEC. It was noted that major stressors altered the permeability of intestinal barriers and profiles of genes and proteins of pro-inflammatory cytokines and chemokines in mucosal system in pigs. However, it is not sufficient to fully explain the mechanism of the gut immune system in pigs under stress conditions. Correlation and interaction of gut and systemic immune system under major stressors should be better defined to overcome aforementioned obstacles. (Key Words: Nutrition, Stress, Gut Immunity, Pigs)
\end{abstract}

\section{INTRODUCTION}

Intestinal mucosa acts primarily as a barrier between inner part of the body and external environment. In livestock animals and humans, large quantities of various food antigens digested and absorbed are immunologically

\footnotetext{
* Corresponding Authors: Sung Woo Kim. Tel: +1-919-513-1494, Fax: +1-919-515-6884, E-mail: sungwoo_kim@ncsu.edu / CheolHeui Yun. Tel: +82-2-880-4802, Fax: +82-2-873-2271, E-mail: cyun@snu.ac.kr

${ }^{2}$ Faculty of Animal Science, Sam Ratulangi University, Manado J1 Kampus Selatan, Manado 95115, Indonesia.

${ }^{3}$ Department of Animal Science, North Carolina State University, Raleigh NC 27695, USA.

${ }^{4}$ Institutes of Green Bio Science and Technology, Seoul National University, Pyeongchang 25354, Korea.

${ }^{5}$ Biomodulation major and Center for Food and Bioconvergence, Seoul National University, Seoul 08826, Korea.

Submitted Feb. 14, 2016; Revised Mar. 29, 2016; Accepted Apr. 22, 2016
}

tolerable in general at intestinal mucosa. Morphology and characteristics of intestinal mucosa together with intestinal immune cells are constantly changing dependent on the food composition. A large number of pathogens, entering the body through the intestinal mucosa, are rapidly eliminated by protective mucosal immune responses. Otherwise, the intestine is normally home to many different commensal bacteria, continuously exposed to food proteins. As a result, the intestinal immune system must be able to discriminate harmless antigens from harmful ones (Wilson et al., 1996).

Status of porcine intestinal immune system is immature at birth, which develops further during perinatal period and then reaches to adult values between 5 and 7 weeks of life. Gut epithelial cells communicate with intestinal innate immune system, forming a functional barrier to antigens from diet and pathogens. Toll-like receptors (TLRs) are emerging as a functionally important class of membrane and cytosolic receptors with key roles in recognition of 
pathogens for innate immune modulation. Induction of adaptive immune responses begins with processing and presentation of antigen by specialized antigen presenting cells (Lee et al., 2014), in the organized tissues of the Peyer's patches or mesenteric lymph nodes in the intestine (Gebert et al., 1996). One of the most important parts of adaptive intestinal immunity would be $\operatorname{IgA}$ responses, which require interactions between $\mathrm{T}$ and $\mathrm{B}$ lymphocytes (Cheon et al., 2014) within gut-associated lymphoid tissues.

Livestock are exposed to various stressors including diet, temperature, weaning and infection. Abrupt changes of these stress factors influence animal health negatively, resulting in lower productivity. Such stressors often challenge homeostasis of animals by inducing systemic or local inflammatory responses coincident with neuroendocrine alteration. Considering the fact that gastrointestinal tract is tightly controlled by a reciprocal circuit composed of the immune system and neuro-endocrine system (Kayama and Takeda, 2012; Hayes et al., 2014), reducing stress would significantly improve gut homeostatic balance of livestock.

Gut immunity is surely one of the most crucial factors in domestic animals that is largely responsible for growth performance and host health. This article will discuss the impacts of stress on gut health and immune status of pigs.

\section{GUT IMMUNITY IN PIGS UNDER VARIOUS STRESSORS}

\section{Heat stress}

Climate change caused by global warming has forced high ambient temperatures in not only tropical regions, but also temperate regions. Heat stress (HS), therefore, is becoming a critical stress factor for health in the swine industry (Upadhyay, 2011). HS has affected an economic loss over 300 million USD per year in USA, and billions of dollars on a global scale (St-Pierre et al., 2003). It is, therefore, important to understand how HS is involving animal growth performance and health status in respect to nutritional and immune correlation, respectively.

It has been shown that destruction of tight junction (TJ) proteins, such as claudin $1 / 3$ and occludin, caused an increase of the permeability of porcine gut epithelial cells ( $\mathrm{Gu}$ et al., 2014). Interestingly, however, HS induced increase of the gut permeability without changing the expression of the TJ proteins while there was up-regulation of GLUT-2 (Pearce et al., 2013). It is to note that activation of SGLT 1, $\mathrm{NA}^{+}$and glucose co-transporter causes an increase in the permeability (Turner et al., 1997). Thus, the expression change of glucose transporter on epithelial cells in porcine by HS is directly associated with the permeability. Although, HS increased the permeability and the concentration of endotoxins in blood was increased over three times, inflammatory cytokines, such as interleukin (IL)-1 $\beta$, IL- 8 and tumor necrosis factor (TNF)- $\alpha$, were not up-regulated (Pearce et al., 2013). Since it is well established that endotoxin (lipopolysaccharide, LPS) is strong inducer of the inflammatory cytokines this study left scope for discovering how this occurs. It is probable that either HS caused immune suppression in the animal (Meng et al., 2013) or LPS was not as high as it appeared due to i) a technical error, ii) structural differences (Trent et al., 2006), iii) differential composition (Im et al., 2015; Lam et al., 2011) or iv) binding proteins of LPS (Lam et al., 2011; Im et al., 2015). It could well be that HS together with LPS does not induce all pro-inflammatory cytokines and perhaps are linked with specific cytokines such as IL-17 and/or transforming growth factor- $\beta$ (TGF- $\beta$ ) which are in relation with regulatory $\mathrm{T}$ (Treg) and Th17 T cells. For example, the colonization of probiotics, such as Lactobacillus rhamnosus strain GG and Bifidobacterium lactis $\mathrm{Bb} 12$, in gnotobiotic pigs impacted to stable the balance of TGF- $\beta$ and IL-17 after rotavirus challenge (Chattha et al., 2013). It has been also suggested that heat shock protein 70 (Pearce et al., 2014) and myeloperoxidase activity as the activation marker of neutrophils (Pearce et al., 2013) were increased under HS in porcine gut. This indirectly suggests that unlike the previous report by the same group, HS induces the inflammatory responses in intestine of pigs.

Taken together, HS induces alteration of barrier function coincident with gut inflammation in pigs. It appears that the influence of HS together with the solution to overcome the effects of HS on pigs' immune system in relation to systemic and local inflammation should be further investigated.

\section{Nutritional stress}

Growth performance is the most critical factor for producers in the pig industry. Therefore, nutritional stress would be the greatest, if not the only, concern for them (Shen et al., 2014; Zhao et al., 2014). In general, fasting negatively impacts porcine gut health in terms of physiology and immunology. Deprivation of feed and/or water for $24 \mathrm{hrs}$ raised the level of cortisol in blood, and suppressed TNF- $\alpha$ expression in jejunum of weaned pigs. Interestingly, there were no disruption of the TJ proteins, including claudin-1, occludin and zonula occludens protein1 (ZO-1) in jejunum and ileum (Horn et al., 2014). Lacking glycine reduced the cell proliferation and protein synthesis, while apoptosis was increased in porcine gut epithelial cells. Coincidently, activation of both Akt and mammalian target of rapamycin (m-TOR) was reduced (Wang et al., 2014).

Mycotoxin is one of the major factors to contaminate animal feed causing nutritional stress (Weaver et al., 2014a). 
Deoxynivalenol (DON) disrupted the expression of the TJ proteins such as ZO-1, occludin and claudin-3, and permeability of porcine gut epithelial cells within $48 \mathrm{hrs}$ (Gu et al., 2014; 2016). DON stimulated pro-inflammatory cytokines like TNF- $\alpha$, IL-6, and IL-1 $\beta$ expression in jejunum and ileum (Bracarense et al., 2012) and increased the number of lymphocytes ( $\mathrm{Wu}$ et al., 2015). It is apparent that TLR2 ligand can prevent the damage of porcine gut epithelial cells treated with DON (Gu et al., 2016). Fumonisin B1 (FB1) increased the permeability in porcine jejunum at over 10 days post stimulation (Bouhet et al., 2004) whilst DON took only 2 days to reach the similar level of the permeability ( $\mathrm{Gu}$ et al., 2014). FB1 appeared to down-regulate the expression of IL-8 without changing other inflammatory cytokines, IL-6, IL-1 $\beta$, IL-12p40, and TNF- $\alpha$ (Bouhet et al., 2006). It is likely that FB1 has relatively weak immunological effects on porcine gut epithelial cells when compared to those of DON. Chronic feeding with the combination of aflatoxin and DON for 33 to 42 days increased the number of monocytes and white blood cells coincident with high concentration of TNF- $\alpha$ in blood while a single treatment did not show such an impact (Chaytor et al., 2011; Weaver et al., 2013). It was noted that a combination of DON and zearalenone feeding for a long time increased twice the level of 8-hydroxydeoxyguanosine indicating oxidative stress, together with DNA oxidative damage (Weaver et al., 2014b). For inflammatory cytokines including IL-12/IL-23p40 and IL$1 \beta$, and vasoactive intestinal peptides were increased in ileum Peyer's patches after 42 days feeding of zearalenone $(0.1 \mathrm{mg} / \mathrm{kg})$ to pigs (Obremski et al., 2015a). While feeding of zearalenone $(0.1 \mathrm{mg} / \mathrm{kg})$ to pigs for 28 days induced a reduction of $\mathrm{CD} 21^{+} \mathrm{B}$ cells while increasing interferon (IFN) $-\gamma$ concentration in ileocecal lymph nodes (Obremski et al., 2015b) suggesting that it may alter B cell responses. In addition, T-2 toxin reduced viability of intestinal epithelial cells in pigs infected with Salmonella Typhimurium. Although T-2 toxin did not alter the integrity of porcine gut epithelial cells, it increased translocation of bacteria (Verbrugghe et al., 2012). Chronic exposure of T-2 toxin at low dose by feeding for 21 days decreased the proportion of $\mathrm{CD} 21^{+}$B cells gradually from ileal Peyer's patches. Besides, gene expression profiles of cytokines in $\mathrm{T}$ cells, such as IL-2, IL-4, and IFN- $\gamma$ were not changed under the same condition (Obremski et al., 2013).

Conclusively, nutritional deficiency or ingestion with contaminated feed induces the change of intestinal proinflammatory cytokines and modulates barrier function in pigs. The immunological mechanism by which nutritional stress induces the modulation of gut immune system resulting in weak host response is yet to be defined.

\section{Infectious stress}

Enteric and respiratory infections are the most frequent and recurrent diseases in swine industry. Especially, enteric infection is one of major stressors causing low productivity in farm animals since it is known to suppress the feed conversion efficiency (Kiarie et al., 2011; Yang et al., 2014). Unlike other type of stressors, infectious stress is not easy to control and often causes long-term economic loss. Once there is an outbreak, transmission within and between the batches of animals occurs very fast because most modern animal farms have adopted intensive rearing system. At the same time, it is difficult to clear the pathogens completely from the site and region of the outbreak without a mass slaughter operation.

Most enteric pathogens come into contact with the animal from drinking water, feeds, or feces from other infected animals. After gaining access to the gut of the target animal, enteric pathogens generally disrupt the homeostasis of the epithelial barrier. Some pathogens including Escherichia coli induce intestinal damage through osmotic stress causing secretory diarrhea while others cause diarrhea by up-regulating pro-inflammatory cytokines, producing so called inflammatory diarrhea (Fairbrother et al., 2005). Enteric pathogens are known to suppress feed intake and feed conversion, which causes unnecessary energy loss for activating immune system. The main causes of enteric diseases in the swine industry are: E. coli, porcine epidemic diarrhea virus (PEDV), porcine delta coronavirus $(\mathrm{PDCoV})$, and transmissible gastroenteritis coronavirus (TGEV).

E. coli is gram-negative, enteric bacteria composed of several strains, although some are pathogenic most are commensal. Pathogenic E. coli, also called enterotoxigenic E. coli (ETEC), has been known to cause diarrhea accompanied by dehydration, inhibition of the feed conversion and growth performance. It was also reported that ETEC shortened the length of villus and the depth of crypt of small intestine. It also inhibited the expression of TJ of intestinal epithelial cells by loosening the epithelial barrier. Supplementation of Lactobacillus plantarum (Yang et al., 2014), Saccharaomyces cerevisiae boulardii (Collier et al., 2011), chitosan (Xiao et al., 2013) or vasoactive intestinal peptide (Xu et al., 2014) has been reported to alleviate the infection stress of ETEC.

PEDV is an enteric coronavirus which had been prevalent only in East Asia, but there have been frequent outbreaks in America since 2013. Once PEDV appears, animal farms seem to suffer chronically because no strategy or treatment is available, even antibiotics have no effect (Song and Park, 2012). It was suggested that PEDV changed the microfilaments inside the epithelial cells followed by increase of permeability of the epithelial barrier through TLR 2, 3, and 9 (Cao et al., 2015). Not only 
epithelial cells but also the immune cells could be targeted by this virus since most immune cells are expressing TLRs. $\mathrm{B}$ cells located in mucosal tissues such as duodenum lamina propria produced much more $\operatorname{IgG}$ and $\operatorname{IgA}$ than those in systemic lymphoid tissues, spleen and blood (de Arriba et al., 2002). In pigs infected with PEDV, monocyte-derived dendritic cells produced a large amount of proinflammatory cytokines including IL-12 coincident with enhancing T-cell proliferation when co-cultured (Gao et al., 2015).

PDCoV and TGEV are less prevalent than E. coli or PEDV but they are still critical enteric coronaviruses in swine industry. PDCoV was once detected in Hong Kong (2009) and USA (2014). The pathology of PDCoV includes dehydration, loss of body weight but with less severe symptoms compared to other pathogens (Chen et al., 2015). However, it is important to note that PDCoV showed synergic pathology when co-infected with PEDV. TGEV was often reported in Asia and America causing vomiting and even death in piglets, when severe. It is assumed that this virus is derived from the same ancestor as porcine respiratory coronavirus which infects respiratory tracts (Kim et al., 2000).

In conclusion, infectious stress causes persistent economic loss of swine industry, especially with chronic infection. Research may have been biased to the treatment and eradication of the pathogens using treatment like antibiotics or vaccines. However, how to increase the disease tolerance in domestic animals against infection is not well understood. It is time to extend our effort to understand infectious stress affecting animal health and growth performance.

\section{CONCLUSION}

Various stressors are threatening the health and, at the same time, suppressing the growth performance in farm animals. The present paper focused on major stress factors, including thermal, nutritional and infectious, in relation to gut immunity in pigs. Numerous studies focusing on stresses in conjunction with porcine gut examined TJ proteins for the permeability, pro-inflammatory cytokines and/or gene profiles (Table 1). However, we do not know enough today to fully explain the precise mechanism of the gut immune system in pigs under stress conditions. In addition, the pig's immune system cannot be directly extrapolated from that of humans and mice, for instance, $\mathrm{CD}^{+} \mathrm{CD}^{+} \mathrm{T}$ cells in peripheral immune system (Cheon et al., 2014). In the near future, studies are expected to define i) the identification and the function of immune cells like innate lymphoid cells in intestine, ii) the immunological interaction between immune cells and gut epithelial cells under major stresses, iii) the alteration of intestinal immune system by major stresses to systemic immune responses and iv) gut health leading host immune system under multistress condition in pigs.

\section{CONFLICT OF INTEREST}

We certify that there is no conflict of interest with any financial organization regarding the material discussed in the manuscript.

Table 1. i) The impact of major stresses on gut immunity

\begin{tabular}{|c|c|c|c|c|}
\hline Stressor & Condition & Sample & Change & Reference \\
\hline \multirow[t]{7}{*}{ Heat } & $35^{\circ} \mathrm{C}$ for $24 \mathrm{hrs}$ & Ileum & $\begin{array}{l}\text { GLUT2 (1.5 times), HSP70 (2 times) and HIF-1 } \alpha \text { (1.5 } \\
\text { times) were upregulated } \\
\text { Myeloperoxidase activity was increased by } 4 \mathrm{U} / \mathrm{mg}\end{array}$ & (Pearce et al., 2013) \\
\hline & & Ileum and colon & $\begin{array}{l}\text { The permeability measured by using TER and FITC- } \\
\text { dextran transport was increased }\end{array}$ & \\
\hline & & Serum & Endotoxin was increased by more than 3 times & \\
\hline & $37^{\circ} \mathrm{C}$ for $6 \mathrm{hrs}$ & Ileum & $\begin{array}{l}\text { Mucin } 2 \text { was increased by } 0.35 \mathrm{ng} / \mathrm{mL} \text { at } 6 \mathrm{hrs} \text { post heat } \\
\text { stress } \\
\text { Villi height was deceased by } 181 \mu \mathrm{m} \text { at } 6 \mathrm{hrs} \text { post heat } \\
\text { stress }\end{array}$ & (Pearce et al., 2014) \\
\hline & & Colon & $\begin{array}{l}\text { HSP70 was increased more than twice at } 2 \text { hrs post heat } \\
\text { stress }\end{array}$ & \\
\hline & & & $\begin{array}{l}\text { The permeability measured by TER, FITC-dextran } \\
\text { transport was increased at } 2 \mathrm{hrs} \text { post heat stress }\end{array}$ & \\
\hline & & Serum & $\begin{array}{l}\text { LBP was decreased at } 2 \text { hrs post heat stress } \\
\text { Endotoxin showed the tendency for a linear increase over } \\
\text { time }\end{array}$ & \\
\hline
\end{tabular}

hrs, hours; GLUT2, glucose transporter 2; HSP70, heat shock protein 70; HIF-1 $\alpha$, hypoxia-inducible factor 1-alpha; TER, transepithelial electrical resistance; FITC, fluorescein isothiocyanate; LBP, LPS binding protein; TNF- $\alpha$, tumor necrosis factor- $\alpha$; DON, deoxynivalenol; m-TOR, mammalian target of rapamycin; WBC, white blood cell; ADG, average daily gain; TER, transepithelial electrical resistance; ZO-1, zonula occludens protein-1; FB, fumonisin B; PEDV, porcine epidemic diarrhea virus; IECs, porcine small intestinal epithelial cells; GRP78, glucose regulated protein 78; dpi, days post inoculation; MNC, mononuclear cells; ASC, antibody secreting cells; MLN, mesenteric lymph nodes; MOI, multiplicity of infection; Mo-DCs, monocytederive dendritic cells; PDCoV, porcine deltacoronavirus. 
Table 1. ii) The impact of major stresses on gut immunity (Continued)

\begin{tabular}{|c|c|c|c|c|}
\hline Stressor & Condition & Sample & Change & Reference \\
\hline \multirow[t]{34}{*}{ Nutrition } & Feed deprivation for $24 \mathrm{hrs}$ & Jejunum & Gene expression of TNF- $\alpha$ was decreased by 4 times & (Horn et al., 2014) \\
\hline & & Serum & Cortisol was increased by $14 \mathrm{ng} / \mathrm{mL}$ & \\
\hline & Glycine depletion & IPEC-1 & Apoptosis was increased by more than $10 \%$ & (Wang et al., 2014) \\
\hline & & & $\begin{array}{l}\text { Activation of Art and m-TOR was reduced by more than } \\
\text { half }\end{array}$ & \\
\hline & $180 \mu \mathrm{g} / \mathrm{kg}$ of $\mathrm{AF}$ and 900 & Serum & WBC increased from 18.4 to $23.4 \times 10^{3} \times 10^{3} / \mu \mathrm{L}$ & (Chaytor et al., \\
\hline & $\mu \mathrm{g} / \mathrm{kg}$ of DON for $33 \mathrm{~d}$ & & TNF $\alpha$ increased from 299 to $335 \mathrm{pg} / \mathrm{mL}$ & 2011) \\
\hline & & & Feed intake reduced from 1.04 to $0.88 \mathrm{~kg} / \mathrm{d}$ & \\
\hline & & & ADG was reduced from 0.52 to $0.41 \mathrm{~kg} / \mathrm{d}$ & \\
\hline & $150 \mu \mathrm{g} / \mathrm{kg}$ of $\mathrm{AF}$ and 1,100 & Serum & Basophil increased from 0.09 to $0.16 \times 10^{3} / \mu \mathrm{L}$ & (Weaver et al., \\
\hline & $\mu \mathrm{g} / \mathrm{kg}$ of DON for $42 \mathrm{~d}$ & & Monocyte increased from 0.97 to $1.43 \times 10^{3} / \mu \mathrm{L}$ & 2013) \\
\hline & & & $\begin{array}{l}\operatorname{lgg} \text { increased from } 10.5 \text { to } 15.1 \mathrm{mg} / \mathrm{mL} \\
\mathrm{IgM} \text { increased from } 3.02 \text { to } 4.39 \mathrm{mg} / \mathrm{mL}\end{array}$ & \\
\hline & $2 \mu \mathrm{g} / \mathrm{mL}$ of DON for $48 \mathrm{hrs}$ & IPEC-J2 & ZO-1, occludin and claudin-3 were decreased & (Gu et al., 2014) \\
\hline & & & Permeability was increased & \\
\hline & $2.8 \mathrm{mg}$ of $\mathrm{DON} / \mathrm{kg}$ feed for & Jejunum & Lesion score was increased by 6 times & (Bracarense et al., \\
\hline & $35 \mathrm{~d}$ & & $\begin{array}{l}\text { Villi was flattened coincident with decreased villi height } \\
\left.\text { Number of goblet cells ( } 3 \text { cells in } 1.5 \mathrm{~mm}^{2}\right) \text { and } \\
\text { lymphocytes }\left(10 \text { cells in } 1.5 \mathrm{~mm}^{2}\right) \text { were decreased } \\
\text { Gene expression of IL-1 } \beta(1.78 \text { times), IL-6 }(2.17 \text { times), } \\
\text { MIP-1 } 1 \beta \text { ( } 1.42 \text { times }) \text { IL-2 (1.8 times) and IL-12p40 (1.71 } \\
\text { times) was increased }\end{array}$ & 2012) \\
\hline & & Ileum & Lesion score was increased by 6 times & \\
\hline & & & Gene expression of IL-1 $\beta$ ( 2 times), TNF- $\alpha$ (1.49 times) & \\
\hline & & & and IL-6 (2.13 times) was increased & \\
\hline & & & E-cadherin and occludin were decreased by more than half & \\
\hline & $5.9 \mathrm{mg}$ of FB $(4.1 \mathrm{mg} \mathrm{FB} 1$ & Jejunum & Lesion score was increased by 4 times & \\
\hline & $\begin{array}{l}+1.8 \mathrm{mg} \mathrm{FB} 2) / \mathrm{kg} \text { feed for } \\
35 \mathrm{~d}\end{array}$ & & & \\
\hline & & & $\begin{array}{l}\text { Gene expression of IFN- } \gamma \text { (1.43 times) and IL-10 (1.51 } \\
\text { times) was increased }\end{array}$ & \\
\hline & & Ileum & Lesion score was increased by 4 times & \\
\hline & & & $\begin{array}{l}\text { Gene expression of IL-1 } \beta \text { (1.73 times) and TNF- } \alpha \text { (1.42 } \\
\text { tiems) were increased }\end{array}$ & \\
\hline & & & Gene expression of occludin was decreased by half & \\
\hline & $\begin{array}{l}0.5 \mathrm{mg} \text { of } \mathrm{FB} 1 / \mathrm{kg} \text { of body } \\
\text { weight } / \text { day for } 7 \mathrm{~d}\end{array}$ & Ileum & Gene expression of IL- 8 was decreased & (Bouhet et al., 2006) \\
\hline & $\begin{array}{l}0-100 \mu \mathrm{M}(0 \text { to } 72.2 \mathrm{mg} / \mathrm{L}) \\
\text { of } \mathrm{FB} 1 \text { for } 4 \mathrm{~d}\end{array}$ & IPEC-1 & IL-8 was decreased in a dose-dependent manner & \\
\hline & $0-500 \mu \mathrm{M} F B 1$ for $28 \mathrm{~d}$ & IPEC-1 & The integrity measured by TER was decreased at 10 days & (Bouhet et al., 2004) \\
\hline & & & post treatment & \\
\hline & $\begin{array}{l}0.1 \mathrm{mg} / \mathrm{kg} \text { of zearalenone } \\
\text { for } 42 \mathrm{~d}\end{array}$ & $\begin{array}{l}\text { Ileum Peyer's } \\
\text { patches }\end{array}$ & $\begin{array}{l}\text { Inflammatory cytokines, including IL-12/IL-23p } 40 \text { and IL- } \\
1 \beta \text {, and vasoactive intestinal peptide were up-regulated } \\
\text { significantly }\end{array}$ & $\begin{array}{l}\text { (Obremski et al., } \\
\text { 2015a) }\end{array}$ \\
\hline & $\begin{array}{l}0.1 \mathrm{mg} / \mathrm{kg} \text { of zearalenone } \\
\text { for } 28 \mathrm{~d}\end{array}$ & $\begin{array}{l}\text { Ileocecal lymph } \\
\text { nodes }\end{array}$ & $\begin{array}{l}\mathrm{CD} 21^{+} \mathrm{B} \text { cells were reduced but, IFN- } \gamma \text { concentration was } \\
\text { increased significantly }\end{array}$ & $\begin{array}{l}\text { (Obremski et al., } \\
\text { 2015b) }\end{array}$ \\
\hline & $\begin{array}{l}2.5 \mathrm{ng} / \mathrm{mL} \text { of T- } 2 \text { toxin for } \\
24 \mathrm{hrs}\end{array}$ & IPEC-J2 & $\begin{array}{l}\text { Viability of intestinal epithelial cells was reduced in half } \\
\text { under Salmonella Typhimurium infection condition }\end{array}$ & $\begin{array}{l}\text { (Verbrugghe et al., } \\
\text { 2012) }\end{array}$ \\
\hline & $\begin{array}{l}1 \mathrm{ng} / \mathrm{mL} \text { of } \mathrm{T}-2 \text { toxin for } 30 \\
\mathrm{~min}\end{array}$ & & $\begin{array}{l}\text { Translocation of Salmonella Typhimurium was } \\
\text { significantly increased }\end{array}$ & \\
\hline & $\begin{array}{l}0.2 \mathrm{mg} / \mathrm{kg} \text { of } \mathrm{T}-2 \text { toxin for } \\
21 \mathrm{~d}\end{array}$ & $\begin{array}{l}\text { Ileal Peyer's } \\
\text { patches }\end{array}$ & $\mathrm{CD} 21^{+} \mathrm{B}$ cells were reduced by about $19 \%$ & $\begin{array}{l}\text { (Obremski et al., } \\
\text { 2013) }\end{array}$ \\
\hline
\end{tabular}

hrs, hours; GLUT2, glucose transporter 2; HSP70, heat shock protein 70; HIF-1 $\alpha$, hypoxia-inducible factor 1-alpha; TER, transepithelial electrical resistance; FITC, fluorescein isothiocyanate; LBP, LPS binding protein; TNF- $\alpha$, tumor necrosis factor- $\alpha$; DON, deoxynivalenol; m-TOR, mammalian target of rapamycin; WBC, white blood cell; ADG, average daily gain; TER, transepithelial electrical resistance; ZO-1, zonula occludens protein-1; FB, fumonisin B; PEDV, porcine epidemic diarrhea virus; IECs, porcine small intestinal epithelial cells; GRP78, glucose regulated protein 78; dpi, days post inoculation; MNC, mononuclear cells; ASC, antibody secreting cells; MLN, mesenteric lymph nodes; MOI, multiplicity of infection; Mo-DCs, monocytederive dendritic cells; PDCoV, porcine deltacoronavirus. 
Table 1. iii) The impact of major stresses on gut immunity (Continued)

\begin{tabular}{|c|c|c|c|c|}
\hline Stressor & Condition & Sample & Change & Reference \\
\hline \multirow[t]{19}{*}{ Infection } & ETEC K88 strain $1 \times 10^{8}$ & Duodenum & Villi height was decreased by $180 \mu \mathrm{m}$ & (Yang et al., 2014) \\
\hline & cfu for $3 \mathrm{~d}$ & Jejunum & $\begin{array}{l}\text { Villi height was decreased by } 200 \mu \mathrm{m} \\
\text { Occludin was decreased by more than half } \\
\text { Gene expression of ZO-1 were decreased by more than } \\
\text { half }\end{array}$ & \\
\hline & Transfection to express & IECs & $\mathrm{NF}-\mathrm{\kappa B}$ activity was increased by twice & (Xu et al., 2013a) \\
\hline & PEDV E protein & & $\begin{array}{l}\text { IL-8 was up-regulated } \\
\text { ER stress was increased (GRP78, as a marker for ER } \\
\text { stress, was increased by } 6 \text { times) }\end{array}$ & \\
\hline & $\begin{array}{l}\text { Transfection to express } \\
\text { PEDV N protein }\end{array}$ & IECs & $\begin{array}{l}\text { S phase in cell cycle was increased } \\
\text { NF- } \mathrm{B} \text { activity was increased by } 3 \text { times } \\
\text { ER stress was increased (GRP } 78 \text { was increased by } 7 \text { times) } \\
\text { IL-8 was up-regulated by } 100 \mathrm{pg} / \mathrm{mL}\end{array}$ & (Xu et al., 2013b) \\
\hline & Orally inoculation with & Feces & PEDV was peaked at $5 \mathrm{dpi}$ and eliminated at $8 \mathrm{dpi}$ & (de Arriba et al., \\
\hline & PEDV for $32 \mathrm{~d}$ & Serum & $\begin{array}{l}\text { PEDV specific IgG titer was increased gradually until } 32 \\
\text { dpi } \\
\text { PEDV specific IgA titer was increased until } 21 \mathrm{dpi}\end{array}$ & 2002) \\
\hline & & Duodenum & $\begin{array}{l}\text { Over } 4 \text { (per } 5 \times 10^{5} \text { MNC) PEDV specific IgM ASC was } \\
\text { exited at } 4 \text { dpi }\end{array}$ & \\
\hline & & & $\begin{array}{l}\text { Over } 20 \text { (per } 5 \times 10^{5} \text { MNC) PEDV specific IgG ASC was } \\
\text { exited at } 21 \mathrm{dpi} \text { and decreased to over } 5 \text { (per } 5 \times 10^{5} \text { MNC) }\end{array}$ & \\
\hline & & & PEDV specific IgG ASC at $25 \mathrm{dpi}$ & \\
\hline & & & $\begin{array}{l}\text { Over } 3 \text { (per } 5 \times 10^{5} \text { MNC) PEDV specific IgA ASC was } \\
\text { exited at } 7 \text { dpi and decreased to over } 2 \text { (per } 5 \times 10^{5} \text { MNC) } \\
\text { PEDV specific IgA ASC at } 21 \mathrm{dpi}\end{array}$ & \\
\hline & & Ileum & $\begin{array}{l}\text { Over } 3.5 \text { (per } 5 \times 10^{5} \text { MNC) PEDV specific IgM ASC was } \\
\text { exited at } 4 \text { dpi }\end{array}$ & \\
\hline & & & $\begin{array}{l}\text { Over } 10 \text { (per } 5 \times 10^{5} \mathrm{MNC} \text { ) PEDV specific IgG ASC was } \\
\text { exited at } 25 \mathrm{dpi}\end{array}$ & \\
\hline & & MLN & $\begin{array}{l}\text { Over } 2 \text { (per } 5 \times 10^{5} \mathrm{MNC} \text { ) PEDV specific IgM ASC was } \\
\text { exited at } 7 \mathrm{dpi}\end{array}$ & \\
\hline & $\begin{array}{l}\text { PEDV } 1 \text { MOI infection for } \\
2 \text { hrs and then washed out, }\end{array}$ & Mo-DCs & $\begin{array}{l}\text { Immature DCs were infected preferentially than mature } \\
\text { DCs }\end{array}$ & (Gao et al., 2015) \\
\hline & cultured $24 \mathrm{hrs}$ & & $\begin{array}{l}\text { Infected mature DCs decreased the expression of } \\
\text { SWC } 3 \mathrm{a}^{+} \mathrm{CD} 1 \mathrm{a}^{+} \text {, SWC } 3 \mathrm{a}^{+} \mathrm{CD} 80 / 86^{+} \text {and SWC } 3 \mathrm{a}^{+} \mathrm{SLA}-\mathrm{II}- \\
\mathrm{DR}^{+} \text {compared mature DCs } \\
\text { The concentration of IL- } 10 \text {, IL- } 12 \text { and IFN- } \gamma \text { from infected } \\
\text { DC were decreased by comparing mature DCs }\end{array}$ & \\
\hline & $\begin{array}{l}10 \mathrm{~mL} \text { of PDCoV } 3 \times 10^{3} \\
\text { TCID } 50 / \mathrm{mL} \text { orally for } 4 \mathrm{~d}\end{array}$ & Middle jejunum & $\begin{array}{l}\text { Villus height was decreased by } 250 \mu \mathrm{m} \\
\text { Crypt depth was increased by } 20 \mu \mathrm{m}\end{array}$ & (Chen et al., 2015) \\
\hline & & Distal jejunum & $\begin{array}{l}\text { Villus height was decreased by } 250 \mu \mathrm{m} \\
\text { Crypt depth was increased by } 30 \mu \mathrm{m}\end{array}$ & \\
\hline & & Ileum & $\begin{array}{l}\text { Villus height was decreased by } 180 \mu \mathrm{m} \\
\text { Crypt depth was increased by } 40 \mu \mathrm{m}\end{array}$ & \\
\hline
\end{tabular}

hrs, hours; GLUT2, glucose transporter 2; HSP70, heat shock protein 70; HIF-1 $\alpha$, hypoxia-inducible factor 1-alpha; TER, transepithelial electrical resistance; FITC, fluorescein isothiocyanate; LBP, LPS binding protein; TNF- $\alpha$, tumor necrosis factor- $\alpha$; DON, deoxynivalenol; m-TOR, mammalian target of rapamycin; WBC, white blood cell; ADG, average daily gain; TER, transepithelial electrical resistance; ZO-1, zonula occludens protein-1; FB, fumonisin B; PEDV, porcine epidemic diarrhea virus; IECs, porcine small intestinal epithelial cells; GRP78, glucose regulated protein 78; dpi, days post inoculation; MNC, mononuclear cells; ASC, antibody secreting cells; MLN, mesenteric lymph nodes; MOI, multiplicity of infection; Mo-DCs, monocytederive dendritic cells; PDCoV, porcine deltacoronavirus.

\section{ACKNOWLEDGMENTS}

This work was supported by a grant from the NextGeneration BioGreen 21 Program (PJ01112401), Rural Development Administration, and Korea Institute of Planning and Evaluation for Technology in Food, Agriculture, Forestry and Fisheries (IPET) through (Agricultural Microbiome R\&D Program) the Strategic Initiative for Microbiomes in Agriculture and Food, funded by Ministry of Agriculture, Food and Rural Affairs (MAFRA), 916004-2, Republic of Korea. This work was also partially supported by a grant from North Carolina Agricultural Foundation (660101), Raleigh, USA.

\section{REFERENCES}

Bouhet, S., E. Hourcade, N. Loiseau, A. Fikry, S. Martinez, M. Roselli, P. Galtier, E. Mengheri, and I. P. Oswald. 2004. The 
mycotoxin fumonisin B1 alters the proliferation and the barrier function of porcine intestinal epithelial cells. Toxicol. Sci. 77:165-171.

Bouhet, S., E. Le Dorze, S. Peres, J. M. Fairbrother, and I. P. Oswald. 2006. Mycotoxin fumonisin B1 selectively downregulates the basal IL-8 expression in pig intestine: in vivo and in vitro studies. Food. Chem. Toxicol. 44:1768-1773.

Bracarense, A. P., J. Lucioli, B. Grenier, G. Drociunas Pacheco, W. D. Moll, G. Schatzmayr, and I. P. Oswald. 2012. Chronic ingestion of deoxynivalenol and fumonisin, alone or in interaction, induces morphological and immunological changes in the intestine of piglets. Br. J. Nutr. 107:1776-1786.

Cao, L., X. Ge, Y. Gao, Y. Ren, X. Ren, and G. Li. 2015. Porcine epidemic diarrhea virus infection induces NF-kappaB activation through the TLR2, TLR3, and TLR9 pathways in porcine intestinal epithelial cells. J. Gen. Virol. 96:1757-1767.

Chattha, K. S., A. N. Vlasova, S. Kandasamy, G. Rajashekara, and L. J. Saif. 2013. Divergent immunomodulating effects of probiotics on $\mathrm{T}$ cell responses to oral attenuated human rotavirus vaccine and virulent human rotavirus infection in a neonatal gnotobiotic piglet disease model. J. Immunol. 191:2446-2456.

Chaytor, A. C., M. T. See, J. A. Hansen, A. L. de Souza, T. F. Middleton, and S. W. Kim. 2011. Effects of chronic exposure of diets with reduced concentrations of aflatoxin and deoxynivalenol on growth and immune status of pigs. J. Anim. Sci. 89:124-135.

Chen, Q., P. Gauger, M. Stafne, J. Thomas, P. Arruda, E. Burrough, D. Madson, J. Brodie, D. Magstadt, R. Derscheid, M. Welch, and J. Zhang. 2015. Pathogenicity and pathogenesis of a United States porcine deltacoronavirus cell culture isolate in 5day-old neonatal piglets. Virology 482:51-59.

Cheon, I. S., S. M. Park, H. J. Lee, J. E. Hong, S. Y. Ji, B. S. Shim, K. H. Kim, P. S. Heo, Y. Y. Kim, H. J. Jung, H. Ka, S. H. Han, M. Song, and C. H. Yun. 2014. Functional characteristics of porcine peripheral $\mathrm{T}$ cells stimulated with IL-2 or IL-2 and PMA. Res. Vet. Sci. 96:54-61.

Collier, C. T., J. A. Carroll, M. A. Ballou, J. D. Starkey, and J. C. Sparks. 2011. Oral administration of Saccharomyces cerevisiae boulardii reduces mortality associated with immune and cortisol responses to Escherichia coli endotoxin in pigs. J. Anim. Sci. 89:52-58.

de Arriba, M. L., A. Carvajal, J. Pozo, and P. Rubio. 2002. Isotypespecific antibody-secreting cells in systemic and mucosal associated lymphoid tissues and antibody responses in serum of conventional pigs inoculated with PEDV. Vet. Immunol. Immunopathol. 84:1-16.

Fairbrother, J. M., E. Nadeau, and C. L. Gyles. 2005. Escherichia coli in postweaning diarrhea in pigs: An update on bacterial types, pathogenesis, and prevention strategies. Anim. Health Res. Rev. 6:17-39.

Gao, Q., S. Zhao, T. Qin, Y. Yin, and Q. Yang. 2015. Effects of porcine epidemic diarrhea virus on porcine monocyte-derived dendritic cells and intestinal dendritic cells. Vet. Microbiol. 179:131-141.

Gebert, A., H. J. Rothkotter, and R. Pabst. 1996. M cells in Peyer's patches of the intestine. Int. Rev. Cytol. 167:91-159.

Gu, M. J., S. K. Song, I. K. Lee, S. Ko, S. E. Han, S. Bae, S. Y. Ji, B. C. Park, K. D. Song, H. K. Lee, S. H. Han, and C. H. Yun. 2016. Barrier protection via Toll-like receptor 2 signaling in porcine intestinal epithelial cells damaged by deoxynivalnol. Vet. Res. 47:25.

Gu, M. J., S. K. Song, S. M. Park, I. K. Lee, and C. H. Yun. 2014. Bacillus subtilis protects porcine intestinal barrier from deoxynivalenol via improved zonula occludens-1 expression. Asian Australas. J. Anim. Sci. 27:580-586.

Hayes, M. R., E. G. Mietlicki-Baase, S. E. Kanoski, and B. C. De Jonghe. 2014. Incretins and amylin: Neuroendocrine communication between the gut, pancreas, and brain in control of food intake and blood glucose. Annu. Rev. Nutr. 34:237-260.

Horn, N., F. Ruch, G. Miller, K. M. Ajuwon, and O. Adeola. 2014. Impact of acute water and feed deprivation events on growth performance, intestinal characteristics, and serum stress markers in weaned pigs. J. Anim. Sci. 92:4407-4416.

Im, J., J. E. Baik, K. W. Kim, S. S. Kang, J. H. Jeon, O. J. Park, H. Y. Kim, K. Y. Kum, C. H. Yun, and S. H. Han. 2015. Enterococcus faecalis lipoteichoic acid suppresses Aggregatibacter actinomycetemcomitans lipopolysaccharideinduced IL-8 expression in human periodontal ligament cells. Int. Immunol. 27:381-391.

Kayama, H. and K. Takeda. 2012. Regulation of intestinal homeostasis by innate and adaptive immunity. Int. Immunol. 24:673-680.

Kiarie, E., S. Bhandari, M. Scott, D. O. Krause, and C. M. Nyachoti. 2011. Growth performance and gastrointestinal microbial ecology responses of piglets receiving Saccharomyces cerevisiae fermentation products after an oral challenge with Escherichia coli (K88). J. Anim. Sci. 89:10621078.

Kim, L., J. Hayes, P. Lewis, A. V. Parwani, K. O. Chang, and L. J. Saif. 2000. Molecular characterization and pathogenesis of transmissible gastroenteritis coronavirus (TGEV) and porcine respiratory coronavirus (PRCV) field isolates co-circulating in a swine herd. Arch. Virol. 145:1133-1147.

Lam, J. S., V. L. Taylor, S. T. Islam, Y. Hao, and D. Kocincova. 2011. Genetic and Functional Diversity of Pseudomonas aeruginosa Lipopolysaccharide. Front. Microbiol. 2:118.

Lee, I. K., Y. M. Son, Y. J. Ju, S. K. Song, M. Gu, K. D. Song, H. C. Lee, J. S. Woo, J. G. Seol, S. M. Park, S. H. Han, and C. H. Yun. 2014. Survival of porcine fibroblasts enhanced by human FasL and dexamethasone-treated human dendritic cells in vitro. Transpl. Immunol. 30:99-106.

Meng, D., Y. Hu, C. Xiao, T. Wei, Q. Zou, and M. Wang. 2013. Chronic heat stress inhibits immune responses to $\mathrm{H} 5 \mathrm{~N} 1$ vaccination through regulating $\mathrm{CD} 4(+) \mathrm{CD} 25(+)$ Foxp3(+) Tregs. Biomed. Res. Int. 2013:160859.

Obremski, K., S. Gonkowski, and P. Wojtacha. 2015a. Zearalenone-induced changes in the lymphoid tissue and mucosal nerve fibers in the porcine ileum. Pol. J. Vet. Sci. 18:357-365.

Obremski, K., P. Podlasz, M. Zmigrodzka, A. Winnicka, M. Wozny, P. Brzuzan, E. Jakimiuk, P. Wojtacha, M. Gajecka, L. Zielonka, and M. Gajecki. 2013. The effect of T-2 toxin on percentages of $\mathrm{CD} 4+, \mathrm{CD} 8+, \mathrm{CD} 4+\mathrm{CD} 8+$ and $\mathrm{CD} 21+$ lymphocytes, and mRNA expression levels of selected cytokines in porcine ileal Peyer's patches. Pol. J. Vet. Sci. 16:341-349.

Obremski, K., P. Wojtacha, P. Podlasz, and M. Zmigrodzka. 2015b. The influence of experimental administration of low zearalenone doses on the expression of Th1 and Th2 cytokines 
and on selected subpopulations of lymphocytes in intestinal lymph nodes. Pol. J. Vet. Sci. 18:489-497.

Pearce, S. C., V. Mani, R. L. Boddicker, J. S. Johnson, T. E. Weber, J. W. Ross, R. P. Rhoads, L. H. Baumgard, and N. K. Gabler. 2013. Heat stress reduces intestinal barrier integrity and favors intestinal glucose transport in growing pigs. PLoS One 8:e70215.

Pearce, S. C., M. V. Sanz-Fernandez, J. H. Hollis, L. H. Baumgard, and N. K. Gabler. 2014. Short-term exposure to heat stress attenuates appetite and intestinal integrity in growing pigs. J. Anim. Sci. 92:5444-5454.

Shen, Y. B., A. C. Weaver, and S. W. Kim. 2014. Effect of feed grade L-methionine on growth performance and gut health in nursery pigs compared with conventional DL-methionine. J. Anim. Sci. 92:5530-5539.

Song, D. and B. Park. 2012. Porcine epidemic diarrhoea virus: A comprehensive review of molecular epidemiology, diagnosis, and vaccines. Virus Genes 44:167-175.

St-Pierre, N. R., B. Cobanov, and G. Schnitkey. 2003. Economic Losses from Heat Stress by US Livestock Industries. J. Dairy Sci. 86:E52-E77.

Trent, M. S., C. M. Stead, A. X. Tran, and J. V. Hankins. 2006. Diversity of endotoxin and its impact on pathogenesis. J. Endotoxin Res. 12:205-223.

Turner, J. R., B. K. Rill, S. L. Carlson, D. Carnes, R. Kerner, R. J. Mrsny, and J. L. Madara. 1997. Physiological regulation of epithelial tight junctions is associated with myosin light-chain phosphorylation. Am. J. Physiol-Cell Phys. 273:C1378-C1385.

Upadhyay, R. C. 2011. Impact of climate change on livestock production and health. Proceeding of the ICICCA. Sri Lanka. pp. 19-39.

Verbrugghe, E., V. Vandenbroucke, M. Dhaenens, N. Shearer, J. Goossens, S. De Saeger, M. Eeckhout, K. D'Herde, A. Thompson, D. Deforce, F. Boyen, B. Leyman, A. Van Parys, P. De Backer, F. Haesebrouck, S. Croubels, and F. Pasmans. 2012. T-2 toxin induced Salmonella Typhimurium intoxication results in decreased Salmonella numbers in the cecum contents of pigs, despite marked effects on Salmonella-host cell interactions. Vet. Res. 43:22.

Wang, W., Z. Wu, G. Lin, S. Hu, B. Wang, Z. Dai, and G. Wu. 2014. Glycine stimulates protein synthesis and inhibits oxidative stress in pig small intestinal epithelial cells. J. Nutr. 144:1540-1548.

Weaver, A. C., J. M. Campbell, J. D. Crenshaw, J. Polo, and S. W. Kim. 2014a. Efficacy of dietary spray dried plasma protein to mitigate the negative effects on performance of pigs fed diets with corn naturally contaminated with multiple mycotoxins. J. Anim. Sci. 92:3878-3886.
Weaver, A. C., M. T. See, J. A. Hansen, Y. B. Kim, A. L. P. De Souza, T. F. Middleton, and S. W. Kim. 2013. The use of feed additives to reduce the effects of aflatoxin and deoxynivalenol on pig growth, organ health and immune status during chronic exposure. Toxins 5:1261-1281.

Weaver, A. C., M. T. See, and S. W. Kim. 2014b. Protective effect of two yeast based feed additives on pigs chronically exposed to deoxynivalenol and zearalenone. Toxins 6:3336-3353.

Wilson, A. D., K. Haverson, K. Southgate, P. W. Bland, C. R. Stokes, and M. Bailey. 1996. Expression of major histocompatibility complex class II antigens on normal porcine intestinal endothelium. Immunology 88:98-103.

Wu, L., P. Liao, L. He, W. Ren, J. Yin, J. Duan, and T. Li. 2015. Growth performance, serum biochemical profile, jejunal morphology, and the expression of nutrients transporter genes in deoxynivalenol (DON)- challenged growing pigs. BMC Vet. Res. 11:144.

Xiao, D., Z. Tang, Y. Yin, B. Zhang, X. Hu, Z. Feng, and J. Wang. 2013. Effects of dietary administering chitosan on growth performance, jejunal morphology, jejunal mucosal sIgA, occludin, claudin-1 and TLR4 expression in weaned piglets challenged by enterotoxigenic Escherichia coli. Int. Immunopharmacol. 17:670-676.

Xu, C., Y. Wang, R. Sun, X. Qiao, X. Shang, and W. Niu. 2014. Modulatory effects of vasoactive intestinal peptide on intestinal mucosal immunity and microbial community of weaned piglets challenged by an enterotoxigenic Escherichia coli (K88). PLoS One 9:e104183.

Xu, X., H. Zhang, Q. Zhang, J. Dong, Y. Liang, Y. Huang, H. J. Liu, and D. Tong. 2013a. Porcine epidemic diarrhea virus E protein causes endoplasmic reticulum stress and up-regulates interleukin-8 expression. Virol. J. 10:26.

Xu, X., H. Zhang, Q. Zhang, Y. Huang, J. Dong, Y. Liang, H. J. Liu, and D. Tong. 2013b. Porcine epidemic diarrhea virus $\mathrm{N}$ protein prolongs S-phase cell cycle, induces endoplasmic reticulum stress, and up-regulates interleukin- 8 expression. Vet. Microbiol. 164:212-221.

Yang, K. M., Z. Y. Jiang, C. T. Zheng, L. Wang, and X. F. Yang. 2014. Effect of Lactobacillus plantarum on diarrhea and intestinal barrier function of young piglets challenged with enterotoxigenic Escherichia coli K88. J. Anim. Sci. 92:14961503.

Zhao, Y., A. C. Weaver, V. Fellner, R. L. Payne, and S. W. Kim. 2014. Amino acid fortified diets for weanling pigs replacing fish meal and whey protein concentrate: Effects on growth, immune status, and gut health. J. Anim. Sci. Biotechnol. 5:57. 